\title{
A Multi-Criteria Optimization Approach for Solar Energy and Wind Power Technologies in Shipping
}

\section{Maria D. Margaritou}

Ph.D. Candidate

Dept. of Maritime Studies School of Maritime \& Industrial Studies University of Piraeus Greece

\section{Ernestos Tzannatos}

Professor

Dept. of Maritime Studies School of Maritime \& Industrial Studies University of Piraeus Greece
The continuous pressure for reducing energy costs, as well as the increasing need to control climate change and air quality degradation has led to a substantial shift in environmental awareness driven through the emergence of stricter policy and legislation. Energy saving efforts must be universal in all energy-intensive sectors, such as industry and transport (whether land, sea or air modes are involved). Sea-borne transport is widely recognised as a major source of exhaust emissions, due to the use of heavy and light oil as the main fuel of onboard combustion engines. Therefore, scientific research is focused on the development and implementation of various technical and operational solutions to reduce the exhaust emissions from ships. Amongst them, the application of shipboard renewable energy technologies may constitute a viable option vis-a-vis to various ship-related technical and operational criteria.

The current work presents the underlying legislative framework which dictates the need to pursue this research challenge, highlights the available options towards conforming to this framework and examines the effectiveness of introducing an onboard renewable hybrid energy system with reference to a particular vessel study.

Keywords: EEDI, energy, hybrid, renewable, shipping, solar, wind.

\section{INTRODUCTION}

It is estimated that the global $\mathrm{CO} 2$ emissions from shipping in 2012 reached 949 million tons, equivalent to $2.7 \%$ of global emissions. Of this quantity, 796 million (or 2.2\%) are attributed to international shipping and the remaining to domestic shipping. $\mathrm{CO} 2$ is the most important greenhouse gas emitted by shipping in terms of quantities and hence in terms of contributing to global warming (Table 1) [1]. The relevant contribution of the remaining gases (methane, nitrous oxide and chlorofluorocarbons) is lower. Medium-term scenarios show that in 2050 , in the absence of reduction policies, $\mathrm{CO} 2$ emissions from ships may increase by $150-250 \%$.

Table 1. CO2 emissions from shipping in relation to global emissions.

\begin{tabular}{|c|c|c|c|c|c|}
\hline \multicolumn{3}{|l|}{} & \multicolumn{4}{|l|}{ Third IMO GHG Study $2014 \mathrm{CO}_{2}$} \\
\hline Year & $\begin{array}{l}\text { Global } \\
\mathrm{CO}_{2}{ }^{1}\end{array}$ & $\begin{array}{l}\text { Total } \\
\text { shipping }\end{array}$ & $\begin{array}{c}\text { \% of } \\
\text { global }\end{array}$ & $\begin{array}{c}\text { International } \\
\text { shipping }\end{array}$ & $\begin{array}{c}\text { \% of } \\
\text { global }\end{array}$ \\
\hline 2007 & 31.409 & 1.100 & 3.5 & 885 & 2.8 \\
\hline 2008 & 32.204 & 1.135 & 3.5 & 921 & 2.9 \\
\hline 2009 & 32.047 & 978 & 3.1 & 855 & 2.7 \\
\hline 2010 & 33.612 & 915 & 2.7 & 771 & 2.3 \\
\hline 2011 & 34.723 & 1.022 & 2.9 & 850 & 2.4 \\
\hline 2012 & 35.640 & 949 & 2.7 & 796 & 2.2 \\
\hline Average & $\mathbf{3 3 . 2 7 3}$ & $\mathbf{1 . 0 1 6}$ & $\mathbf{3 . 1}$ & $\mathbf{8 4 6}$ & $\mathbf{2 . 6}$ \\
\hline
\end{tabular}

Received: January 2018, Accepted: March 2018

Correspondence to: Ernestos Tzannatos

Department of Maritime Studies, University of Piraeus,

Karaoli \& Dimitriou St. 80, Piraeus 185 34, Greece

E-mail: et@unipi.gr

doi:10.5937/fmet1803374M

(C) Faculty of Mechanical Engineering, Belgrade. All rights reserved
International regulations to deal with the problem of ship emissions entered into force first time in 2005 with MARPOL Annex VI (International Convention for the Prevention of Pollution from Ships). Through its provisions, MARPOL sets maximum permissible emission limits on all major pollutants. Following successive reviews, MARPOL Part VI set a maximum sulphur content of $3.5 \%$ w.t. of the fuel oil used by ships till 2020 and $0.5 \%$ w.t. after 2020 in order to control $\mathrm{SO}_{\mathrm{x}}$ and introduced technical measures for the reduction of $\mathrm{NO}_{\mathrm{x}}$ emissions. Furthermore, Annex VI contains a provision for specific Emission Control Areas (ECAs) where stricter sulphur content $(0.1 \%$ w.t. from 2015$)$ and $\mathrm{NO}_{\mathrm{x}}$ limits apply.

IMO's MEPC with ongoing revisions (MEPC 53 (2005), MEPC 55 (2006), MEPC 57 (2008), MEPC 58 (2008), MEPC.203 (62) - EEDI) sets stricter emission limits for greenhouse gases. On 1 January 2013 the provisions of the new Chapter 4 of MARPOL Annex VI entered into force introducing measures aimed at improving the energy efficiency in shipping in order to reduce fuel consumptionand ultimately $\mathrm{CO} 2$ emissions. Regulation 21 of Chapter 4 introduces the Energy Efficiency Design Index (EEDI), which concerns technical measures and is mandatory for new ships, while Regulation 22 introduces a mandatory Ship Energy Efficiency Management Plan - SEEMP), which refers to operational measures, for all ships (new and existing). In order for a ship to obtain the International Energy Efficiency Certificate (IEEC), it should comply with the requirements for EEDI and SEEMP.

In general, the EU is in line with the IMO regulations on Air Pollution from Ships. At the same time, however, it works unilaterally to develop Euro- 
pean regulations, which are tighter for ships flying the European flag or docking European ports.

Directive 2005/33/EC impose sulphur limit for $1.5 \%$ w.t. to passenger ships operating on schedule nonSECA services. Furthermore, this directive provided that from 1 January 2010 Member States should take all necessary measures to ensure that ships bound or anchored in EU ports do not use fuel with a content in sulphur greater than $0.1 \%$ w.t. This provision shall not apply to ships which remain in ports for less than 2 hours, as well as to ships that turn off all engines and use offshore energy. It applies to all vessels regardless of the flag, type, age or tonnage. In practice, ships will have to change their fuel from heavy fuel (HFO) to light (MGO) in European ports.

In November 2012, Directive 2012/33/EU was adopted, which again amended Directive 1992/32/EC, further reducing the sulphur content of fuels in and out of ECAs in line with the MARPOL Annex VI regulations.

With regard to $\mathrm{CO} 2$ emissions from shipping, in the 2011 White Paper on Transport, the European Commission states that overall $\mathrm{CO} 2$ emissions from shipping should be reduced by $40 \%$ (and possibly by $50 \%$ ) to 2050 , compared to 2005 levels.

Based on this objective, the European Commission proposes a new system for Monitoring, Reporting and Verification (MRV) forCO2 emission controlapplicable to ships of over 5,000 gt calling at EU ports.

The international framework for reducing all anthropogenic greenhouse gas emissions is set by the UN Framework Convention on Climate Change (entered into force in 1994). For the implementation of the Framework Convention, the Kyoto Protocol was adopted in 1997 (Article 2.2 refers to the need for cooperation with the IMO and ICAO).

Within the above international and European legislative framework for tackling the problem of air pollution and climate change from shipping, it is now urgent to explore the application of all possible emission control technologies to new or existing ships.

\section{OVERVIEW OF AVAILABLE OPTIONS}

Apart from strictly operational measures (e.g. weather routing, trim optimization etc), there are many measures relevant to marine fuel and machinery which can be utilised to reduce air pollution and control climate change, many of which are already available on a large scale and are readily applicable. These include:

- Use of low-sulphur fuels: is the easiest way to decreaseSOX pollutants from ships and substantially reduce $\mathrm{PM}$ emissions too.

- Scrubbers: a possible alternative to low-sulphur fuels, will reduce $\mathrm{SO} 2$ emissions by $99 \%$ and will significantly reduce emissions of other pollutants, but there are still some concerns about the by-products they produce during the cleaning process.

- Internal engine modifications - such as water injection and exhaust gas recirculation: these are techniques to prevent NOX production during the combustion process and can reduce NOX emissions by 30 to $50 \%$.
- Humidifier: adding water vapor to the combustion air, NOx emissions could be reduced by 70 to $85 \%$.

- SCR (Selective Catalytic Reduction): exhaust afterproduction system but prior to actual emission. SCR can cut NOX up to $95 \%$. It is already used on around 500 ships worldwide and works best with low-sulphur fuels.

- Dual fuel or Gas engines: main engines of new or retrofitted ships can operate on liquefied natural gas (LNG) which does not contain sulphur and therefore SOXand PM emissions come close to zero.

- Shore-side electricity (cold ironing): it can be used while ships are at berth and can reduce emissions of SOX, NOx and other PM by up to $90 \%$ ([2] and [3]).

- Alternative energy sources: experiments with wind and solar energy, biofuels and fuel cells are in progress and could be useful in the future.

With regard to the fuel alternatives, major questions arise in relation to there global availability, cost and safety.

High sulphur fuel - HFO (3.5\% w.t.) can be used and is widely available, showing the low price advantage, but should be combined with an exhaust purification system. Low Sulphur Oil - LSMGO and other types of fuel will be available on the market but their cost will be high and their availability around the globe will be limited. Finally, alternative fuels such as liquified natural gas (LNG) are mainly targeted at newbuildings, as the cost forre-engining existing ships is very high. Furthemore, the cryogenic onboard storage and treatment characteristics of LNG pose significant safety requirements.Finally, serious doubts dominate the international shipping industry in relation to the global variation ofLNG prices and the limited availability of LNG bunkering facilities.

In general, it is not easy to predict the price of marine fuels, as unpredicable factors such as geopolitics play a dominant role in the fossil energy market. The production of petroleum products within the defined sulphur limits may lead to large variations in the prices of competing products [4]. As long as the production of low-sulphur sulphur fuel $(0.5 \%$ w.t. $)$ is expanding, its cost is bound to rise due to the increased demand for fuel de-sulphurisation against a limited throughput capacity of refinaries in need of further investment. Currently, demand for high sulphur marine fuel (HFOHeavy Fuel Oil) amounts to 7.3 million barrels per day $(\mathrm{Mb} / \mathrm{d})$. A recent market analysis predicted that by 2020 approximately 2 million barrels of the abovementioned quantity will be converted to low sulphur (LSMGO).

Taking into account all of the above, it appears that technologies based on renewable energy sources present a favourable option towards the reduction of fuel consumption and ultimately air pollution from ships.

The shipboard use of renewable forms of energy can transform the global maritime fleet of whatever type and size, including international and local transport of goods, passengers and services, fisheries, tourism and other maritime activities.

Renewable energy applications on ships include primary, hybrid and/or auxiliary propulsion systems as well as systems for on-board and offshore installations. Possible renewable energy sources for use in shipping include: 
- Wind energy (e.g. soft sails, fixed wings, rotors, kites, and conventional wind turbines) (e.g. soft sails, fixed wings, rotors, kites and conventional wind turbines).

- Solar energy (photovoltaics)

- Biofuels

- Sea wave action

- Use of superconductors to be charged by the above.

These clean energy solutions can be integrated through conversions into the existing fleet or used in the design and construction of new ships, while a very small number of ships may be suitable for $100 \%$ use of renewable energy and zero emissions for the primary propulsion system.

Focusing specifically on the needs of a country such as Greece, it can be concluded that the qualitative and in particular the environmental upgrading of the domestic passenger shipping through the utilisation of the significant solar and wind potential of our country must be investigated. This position is based on the twofold impact of both the economic and environmental challenges faced by this industry, being fuel-intensive (due to its characteristics (network scale, frequency, etc.) and operating within the unique natural and cultural environment of Greece.

Upgrading a ship's energy efficiency and consequently reducing fuel usage and emissions by installing hybrid photovoltaic-wind turbine generator systems can be achieved through implementing several installation scenarios [5]. However, the question is which scenario will bring maximum financial benefits with reference to fuel savings versus intial and operational costs.

\section{MULTI-CRITERIA APPROACH}

\subsection{Multi-criteria analysis application on energy upgrade of ships}

The choice of theappropriate hybrid system is shipspecific, because it depends on a number of factors directly related to the ship's characteristics such as:

- ship type and design,

- ship's sailing speed

- ship's route

- ship's (auxiliary) electrical loads,

- ship's operational profile.

The choice of the system also depends on itsdetailed technical characteristics in relation to the natural and working environment. Consideration should be given to parameters such as wind, humidity, shading, corrosion, onboard space availability for placing PV panels or turbine rotors as well as electricity stogage devices (batteries) and system connectivity issues.

The purpose of this research is to translate this discussion into a mathematical model and be treated as an optimization problem by the multi-criteria analysis method. This will be done by developing a user-friendly decision-making system (DMS) in a user-friendly webbased environment that will provide economic and energy assessment of applying a combined system of photovoltaics and wind turbines generator system to vessels operating in Greek ferry and coastal lines.

It has already been reported that the field of the current research refers to the installation of hybrid systems in domestic passenger ships. The parameters to be emphasized are the ship's category with its parameters, ship's route (route location, time of cruise, etc.), technical specifications of equipment and installation technology, solar density, wind intensity and pollutant emission. Emission estimates will either take into account fuel consumption or installed capacity. The load requirements to be met by the hybrid system to be installed relate only "hotel" loads covered by auxiliary engines [6].

\subsection{Methodology}

The methodology is structured according to the following stages:

Step 1: Identification of ship types

It has already been mentioned that the field of research will be limited to the domestic passenger shipping in Greece, hence reference is made to all ship types employed in this sector.

Step 2: Data requirements and retrieval sources

- Basic and detailed ship design characteristics from globally and nationally held fleet data bases, shipyards and shipping companies.

- Real-life operational characteristics (e.g. auxiliary fuel consumption etc) and scenarios (e.g. itineraries etc) for specific ships from shipping companies.

-Detailed design and functional specifications of photovoltaic and wind turbine systems and associated equipment (e.g. monocrystalline panels, polycrystalline panels, deep discharge batteries, horizontal axis wind turbines, vertical axis etc.) and price quotations from open literature as well as from commercial companies.

- Exhaust emission coefficients from research literature. Step 3: Solar density, geographical coordinates Considering that solar density varies according to geographic coordinates, sea areas will be divided into zones.

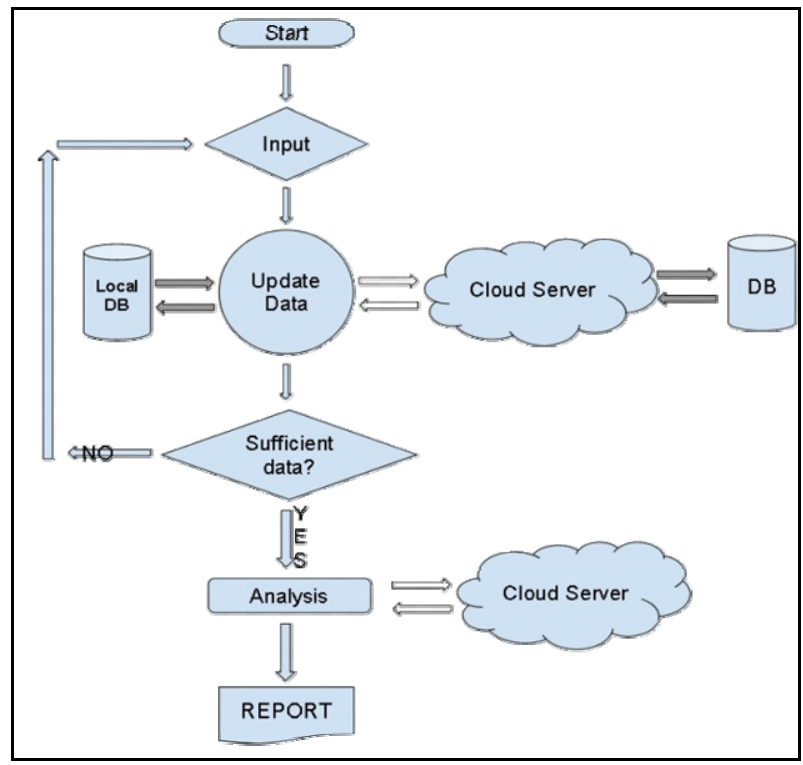

Figure 1. Flow diagram of the proposed application software.

Step 4: Formatting the Mathematical Model Problem - Determination of the mathematical model in each ship category. For each ship category we will identify the 
objective functions of the problem, set restrictive criteria, variables and fixed parameters.

- Database Development. A database on installation costs and pollutant emissions per category of ship will be developed.

- Development of an algorithm. An algorithm to solve the optimal solution selection problem will be developed by the multi-criteria analysis method. A flow chart diagram of data entries and resultsexport is shown below in Figure 1.

\subsection{The proposed multi-criteria approach}

In this section will be defined decision variables, objective functions, constraints and finally the mathematical modeling of the problem that lead to the desired solution.

- Decision variables. As has already been mentioned, this research deals only with the optimal application of a hybrid system of combined installation of a photovoltaic - wind turbine generator.

- Objective Functions. The objective functions describe mathematically the criteria taken into account, as a function of the decision variables.

$\underline{\text { Investment costs by implementing ESM (ReCost) }}$

$$
\operatorname{ReCost}=\operatorname{ReCost}(p v) i+\operatorname{ReCost}(a g t) j
$$

$\operatorname{ReCost}(p v) i$ : installation cost of photovoltaic system i: cost of each equipment

ReCost(agt)j: installation cost of wind turbine generator system

$\mathrm{j}$ :cost of each equipment

\section{Energy Saving (ES)}

The energy that will produced by the implemented system is:

$$
\mathrm{ES}=\mathrm{ES}(\mathrm{pv})+\mathrm{ES} \text { (agt) }
$$

ES(pv):Energy saving by PV system

ES(agt): Energy saving by wind turbine system.

Energy saving could be also the reduction of fuel consuming, or the reduction of emissions such as $\mathrm{CO} 2$.

Energy saving will be calculated either by knowing the power of each ship and the specific fuel consumption of the fuel is used each time, either by knowing the fuel consumption for each ship trip.

- Multi-criteria optimization approach by studying the simultaneous effect of variables

In this section an optimization approach to the problem is applied, taking into account all possible combinations of materials, type of installation, rate of participation pv system and wind turbine system. Furthermore, an optimized solution can be reached by setting as criterion the maximum hotel loads to be covered by pv-agt system, the maximum reduction of fuel consumption, the minimum cost of installation ([7], [8] and [9]) etc.

$$
\begin{aligned}
& \operatorname{MinReCost}{ }_{\text {sim }}=\operatorname{Min}(\operatorname{ReCost}(\mathrm{i}, \mathrm{j},)) \\
& \operatorname{MaxES}_{\text {sim }}=\operatorname{Max}(\operatorname{ES}(\mathrm{i}, \mathrm{j},))
\end{aligned}
$$

OptimumZ1 $=\mathrm{w}_{1} \times$ MinReCost $_{\text {sim }}+\mathrm{w}_{2} \times \operatorname{MaxES}_{\mathrm{sim}}$ $\mathrm{w}_{1}=$ cost weighting factor investment

$\mathrm{w}_{2}=$ energy saving weighting factor

$$
\sum_{i=1}^{2} w_{1}=1
$$$$
\text { i }(1,2, \ldots, I)
$$$$
\text { j }(1,2, \ldots, J)
$$

\section{CASE STUDY}

In this section, the reduction of fuel consumption and emissions is calculated for a specific ship scenario (type of ship, route, speed, time at sea, time at port) knowing the fuel consumption per day and the required equipment of the installation The type of PV panels is identified and the available area for the installation is $200 \mathrm{~m}^{2}$.

Specifically, the used data ispresented in Table 2 and Table 3 .

Table 2. Sip operational scenario.

\begin{tabular}{|c|c|c|c|c|}
\hline$W$ & $L$ & $T$ & $T$ & $V$ \\
\hline 1662 & 95 & 0.125 & 0.125 & 23.5 \\
\hline
\end{tabular}

$W$ is the ship's payload (tons)

$L$ is the port to port sailing distance (nm)

$T$ is the time ship is loading at port (days)

$t$ is time ship is unloading at port (days)

$V$ is the ship's sailing speed (knots)

Table 3. Fuel consumption and emissions for specific ship operational scenario

\begin{tabular}{|c|c|c|c|c|c|}
\hline$G$ & $F$ & $g$ & $F$ & $s$ & $B e$ \\
\hline 4.8 & 63.6 & 4.8 & 63.6 & 0.035 & 183 \\
\hline
\end{tabular}

$G$ is the fuel consuption at loading port (tons/day)

$F$ is the fuel consuption at sea, (tons/day)

$g$ is the fuel consuption at discharging port (tons/day)

$s$ is the percentage of sulphur present in the fuel $(4 \%$, $1.5 \%, 0.5 \%$ and other)

$B e$ is the specific fuel consuption ( $\mathrm{kg} /$ hour)

This data could simulate a Ro-Pax vessel on the route of Piraeus-Paros (island). The exported results for this kind of ship and senario, are presented in Table 4 and Table 5.

Table 4. Fuel consumption and emissions for specific ship operational scenario.

\begin{tabular}{|c|c|c|c|c|c|c|}
\hline$T_{t}$ & $F_{p r t}$ & $\mathrm{E}_{\mathrm{CO} 2}$ & $F_{p r t s}$ & $F_{p r t p}$ & $\mathrm{E}_{\mathrm{CO} 2 \mathrm{~S}}$ & $\mathrm{E}_{\mathrm{CO} 2 \mathrm{P}}$ \\
\hline 4.04 & 22.63 & 71.72 & 21.43 & 1.20 & 67.92 & 3.80 \\
\hline
\end{tabular}

$T_{t}$ is the sailing time from port to port

$F_{p r t}$ is the total fuel consuption per round trip (tons)

$E_{\mathrm{CO} 2}$ is the $\mathrm{CO} 2$ emissions per round trip (tons)

$F_{p r t s}$ is the total fuel consuption per round trip, at sea (tons)

$F_{p r t p}$ is the total fuel consuption per round trip, at port (tons)

$E_{\mathrm{CO} 2 \mathrm{~S}}$ is the $\mathrm{CO} 2$ emissions per round trip, at sea (tons)

$E_{\mathrm{CO} 2 \mathrm{P}}$ is the $\mathrm{CO} 2$ emissions per round trip, at port (tons)

For the specific ship scenario, the fuel consumption per round trip is 22.63 tons, and the $\mathrm{CO} 2$ emissions per round trip are 71.72 tons [10].

Assuming a trip per day, the total emissions $\mathrm{CO} 2$ per year will reach the amount of 26,178 tons. 
By assuming that the PV system is identified with specific technical characteristics, shown at Table 6, the results for numerous cases of power requirements to be covered by the system are shown in Table 7 .

Table 5. Power consumption for specific ship operational scenario.

\begin{tabular}{|c|c|}
\hline $\mathbf{P}_{\mathbf{S}}$ & $\mathbf{P}_{\mathbf{P}}$ \\
\hline 42,985 & 4,371 \\
\hline
\end{tabular}

$P_{S}$ is the power consuption, at sea (KW/day)

$P_{P}$ is the power consuption, at port (KW/day)

Table 6. Technical characteristics of PV system.

\begin{tabular}{|c|c|c|c|c|c|c|}
\hline$W_{p}$ & $V$ & $L_{d p}$ & $W_{d p}$ & $A_{p p}$ & $W_{w}$ & $T_{p}$ \\
\hline 55 & 12 & 0.878 & 0.520 & 0.435 & 3.31 & $\mathrm{Mc}$ \\
\hline
\end{tabular}

$W_{p}$ is the maximum power per panel (watt)

$V$ is the operational voltage

$L_{d p}$ is the panel length

$W_{d p}$ is the panel width

$A_{p p}$ is the panel area

$W_{w}$ is the panel weight

$T_{p}$ is the panel type (monocrystalic or polycrystalic)

Table 7. Consumptions and emissions of specific ship operational scenario by installing a PV system.

\begin{tabular}{|c|c|c|c|c|l|c|c|}
\hline$P_{D}$ & $N_{P}$ & $A_{t p}$ & $P_{p d}$ & $P_{c \%}$ & $F_{r}$ & $E_{r c o 2}$ & $E_{y r}$ \\
\hline 20 & 87 & 38 & 282 & 0.6 & 0.004 & 0.01 & 4.23 \\
\hline 40 & 175 & 76 & 536 & 1.19 & 0.007 & 0.02 & 8.47 \\
\hline 60 & 262 & 114 & 845 & 1.78 & 0.011 & 0.03 & 1.7 \\
\hline 80 & 349 & 152 & 1127 & 2.38 & 0.015 & 0.05 & 16.9 \\
\hline 100 & 436 & 190 & 1404 & 2.97 & 0.018 & 0.06 & 21.2 \\
\hline 120 & 524 & 228 & 1690 & 3.57 & 0.022 & 0.07 & 25.4 \\
\hline 140 & 611 & 266 & 1972 & 4.16 & 0.026 & 0.08 & 29.6 \\
\hline
\end{tabular}

Where

$P_{D}$ is the desired power to be produced (KWh)

$N_{p}$ is the required number of panels to cover the desired power

$A_{t p}$ is the covered area from the total installed panels $(\mathrm{m}, 2)$

$P_{p d}$ is thepower the pv system is called to cover per day (KW/day)

$P_{c \%}$ is the load percentagecoverage

$F_{r}$ is the reduction of fuel consuption by installing the PV system (tons/day)

$E_{\text {rco2 }}$ is the reduction of $\mathrm{CO}_{2}$ emissions per day by installing the PV system (tons/day)

$E_{y r}$ is is the reduction of $\mathrm{CO}_{2}$ emissions per year by installing the PV system (tons/year)

By observing the results of Table 7, Figures 3 and 4 various comments can be made. The most important is that the optimized result depends on the set target. More particularly, if the target of the impenting installation is to cover the maximum needed power, by installing a PV system in a restricted area of $200 \mathrm{~m}^{2}$, then the solution is obviously to install a PV system which can cover 100 $\mathrm{KW}$ of power. The particular PV system is equipped with 436 monocrystalic panels and produces 1404 $\mathrm{KW} /$ day. The fuel reduction by installing this system would be 0.018 tons/day and the reduction of $\mathrm{CO}_{2}$ emissions would be 0.06 tons/day or 21.2 tons/year.

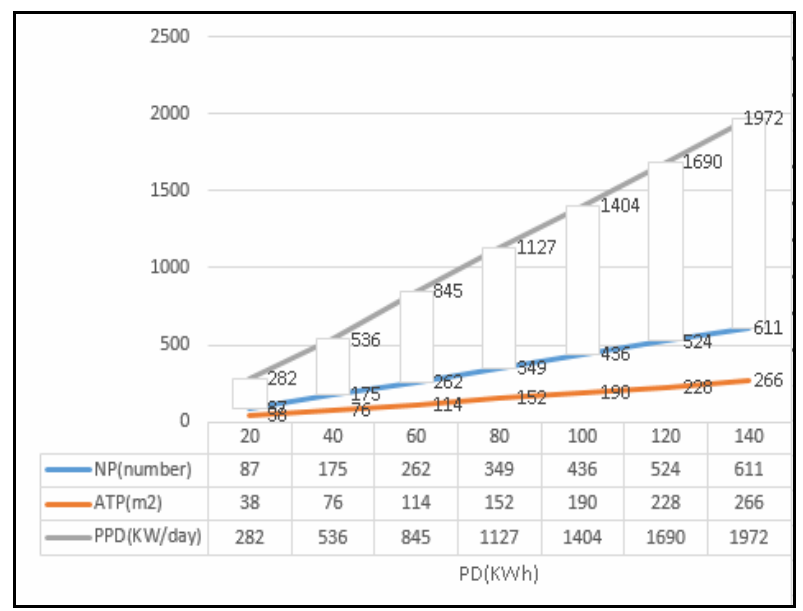

Figure 3: Number of panels, panel area coverage, power the PV system is capable to produce per day compared with desired covered power needs.

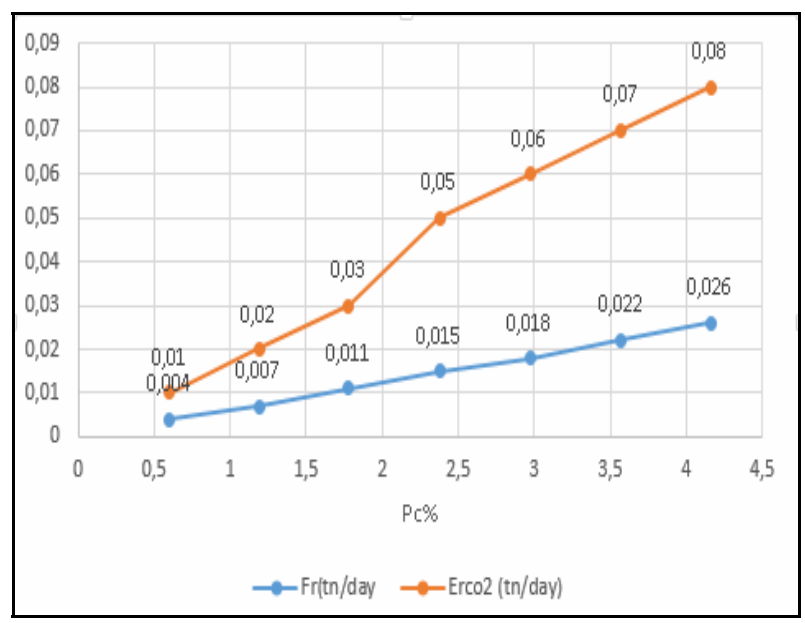

Figure 4: Reduction of fuel consuption and CO2 emissions per percentage coverage of load by PV system.

The solar energy produced per month by installing the specific kind of PV system is presented in Table 8 . The results of the produced energy in relation to what is required are presented in Figure5.

Table 8. Monthly distribution of PV energy production.

\begin{tabular}{|c|c|c|c|c|}
\hline $\begin{array}{c}\text { Solar } \\
\text { Energy } \\
\left(\mathrm{kWh} / \mathrm{m}^{2}\right) \\
(\mathrm{month})\end{array}$ & $\begin{array}{c}\text { Solar } \\
\text { Energy } \\
(\mathrm{kWh}) \\
(\mathrm{month})\end{array}$ & $\begin{array}{c}\text { Solar } \\
\text { Energy } \\
(\mathrm{Wh} / \text { day })\end{array}$ & $\begin{array}{c}\text { Desirable } \\
\text { installed } \\
\text { power } \\
(\mathrm{Wh} / \text { day })\end{array}$ & Months \\
\hline 86 & 16324 & 73460 & 100000 & January \\
\hline 97 & 18412 & 82856 & 100000 & February \\
\hline 126 & 23917 & 107627 & 100000 & March \\
\hline 151 & 28663 & 128981 & 100000 & April \\
\hline 181 & 34357 & 154607 & 100000 & May \\
\hline 188 & 35686 & 160586 & 100000 & June \\
\hline 204 & 38723 & 174253 & 100000 & July \\
\hline 202 & 38343 & 172545 & 100000 & August \\
\hline 166 & 31510 & 141794 & 100000 & September \\
\hline 133 & 25246 & 113606 & 100000 & October \\
\hline 104 & 19741 & 88835 & 100000 & November \\
\hline 85 & 16135 & 72605 & 100000 & December \\
\hline
\end{tabular}

If the target to be met was a minimum load percentage coverage $2 \%$, the optimized solution would be to install a PV system that could produce $1127 \mathrm{KW} /$ day. Such a system would cover $80 \mathrm{KW}$ of power and would be equipped with 349 panels. The fuel reduction 
by installing this system would be 0.015 tons/day and the reduction of $\mathrm{CO}_{2}$ emissions would be 0.05 tons/day or 16.9 tons/year.

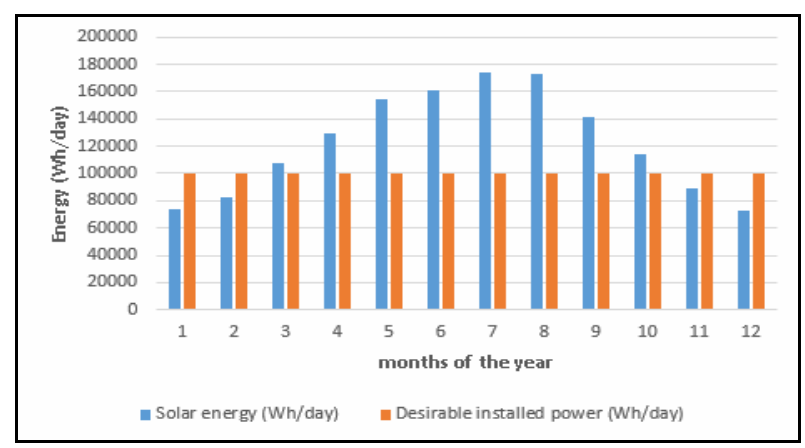

Figure 5. Montly distribution of PV produced versus required energy.

\section{CONCLUSIONS}

The most important conclusion is that the optimized result depends on the target set. The identified target includes set criterias depending on each case every time.

In the previous section, a case study is presented by using a multi-criterion optimization approach. The restricted critiria was the identified ship scenario, the identified type of panels and the available area for installing the pv system. in the back of our minds, there was also taken into account the minimum cost of the installation by having maximum energy production.

In case the covered load for this kind of ship should be $10 \mathrm{kWh}$ per day, a $2 \mathrm{kWp}$ PV system could be installed consisting of 44 monocrystalic panels of $55 \mathrm{Wp}$ each. Taking into account that the total $\mathrm{CO} 2$ emissions per year are 26,178 tons, , the $\mathrm{CO} 2$ emission reduction will be 2,177 tons per year by installing this PV system capable to cover a load percentage of $0.3 \%$.

In the case a target of $\mathrm{CO}_{2}$ emission reduction is set up to $3 \%$, the required PV system should be $24 \mathrm{kWp}$, consistingof 436panels of $55 \mathrm{Wp}$ each, installed over an area $190 \mathrm{~m}^{2}$. This solution refers to the minimum cost of installation by setting as a restricted critirion the minimum reduction of $\mathrm{CO}_{2}$ emissions. As shown in Table 7, the optimized solution for this case study is to establish 436 monocrystalic panels. The target could also be met by installing 524 panels or more, but in those cases their cost would not be minimum.

In case a target is set for covering all power needs by installing a PV system and the available area for the installation is less than that required, a wind turbine generator system can also be used [11]. The latter when employed in combination with the PV system acts as a complementary source of energy in case of low photovoltaic system efficiency (cloudy days, evening hours, winter, etc). The power mix of each system depends on the set targets (e.g. reduce of $\mathrm{CO} 2$ emissions, loads to be covered by free emissions system, etc), the technical specifications of each system, on the available area etc.

There is a plurality of combined solutions. In simple case studies, it is easy to find a good solution by using experience, taking into account a number of critiria. In case of composed projects or great investments, the proposed solution should be the optimal one, because anything else could cause high financial damage. In such cases, a multi-criteria approach for the optimal solution should be applied. That approach could also cost both time and money because a case study should be prepared at each project, something which may act adversely on potential investors. This disadvantage could be overcome if there was a decision-support system available, whereby the prospective investor through setting his criteria could quickly arrive at the most advantageous solutions and ultimately at the optimum solution for his case.

By applying the multi-criteria analysis to a decision support system in a form of user-friendly software, the optimum solution will be exported very quickly, without spending substantial time and money. This kind of solution not only prevents choosing a non optimal solution but also encourages owners of private companies to invest in renewable energy technologies on ships.

\section{REFERENCES}

[1] Smith, T. W. P., Jalkanen, J. P., Anderson, B. A., Corbett, J. J., Faber, J., Hanayama, S., O'Keeffe, E., Parker, S., Johansson, L., Aldous, L., Raucci, C., Traut, M., Ettinger, S., Nelissen, D., Lee, D. S., $\mathrm{Ng}$, S., Agrawal, A., Winebrake, J. J., Hoen, M., Chesworth, S., Pandey, A.: Third IMO GHG Study 2014, International Maritime Organization (IMO ) London, UK, April 2015, 2015.

[2] Nikitakos, N.: Green Logistics - The Concept of Zero Emissions Port, FME Transactions, Vol. 40, No. 4, pp. 201-206, 2012.

[3] Tzannatos, E.: Cost assessment of ship emission reduction methods at berth:The case of the Port of Piraeus - Greece, Maritime Policy \& Management, Vol. 37, No. 4, pp. 427-445, 2010.

[4] Glykas A., Papaioannou G., Perissakis S.: Application and cost benefit analysis of solar hybrid power installation on merchant marine vessels, Ocean Engineering, Vol. 37, No. 7, pp. 592-602, 2010.

[5] Asadi, E., Gameiro da Silva, M., Hengeller Antunes, C., Dias, L.: A multi-objective optimization model for building retrofit strategies using TRNSYS simulatios, GenOpt and MATLAB, Building and Environment, Vol. 56, pp. 370-378, 2012.

[6] London Royal Academy of Engineering: Future Ship Powering Options, Exploring alternative methods of ship propulsion, 2013.

[7] Moustafa, M.M., El-bokl, E.: Solar Energy for river nile cruises,Shipbuilding, Vol. 62, No. 2, pp. 61-72, 2014.

[8] Salem, A.A., Seddiek, I.S: Techno-Economic Approach to Solar Energy Systems onboard Marine Vehicles.,Polish Maritime Research, Vol. 23, No. 3, pp. 64-71, 2016.

[9] Bakic, V., Pezo, M., Stojkovic, S.: Technical and economic analysis of Grid- Connected PV/Wind energy stations in the republic of serbia under 
varying climatic conditions, FME Transactions, Vol. 44, No. 1, pp. 71-82, 2016.

[10] Hellenic Chamber of shipping: Ship Emissions Study, National Technical University of Athens, May 2008, 2008.

[11] Lakatos, L., Hevessy, G., Kovács, J.: Advantages and disadvantages of solar energy and wind power utilization, World Futures, The Journal of New Paradigm Research, Vol. 67, No. 6, pp. 395-408, 2011.

\section{ПРИСТУП ВИШЕКРИТЕРИЈУМСКЕ \\ ОПТИМИЗАЦИЈЕ ТЕХНОЛОГИЈИ СУНЧЕВЕ ЕНЕРГИЈЕ И СНАГЕ ВЕТРА У БРОДАРСТВУ}

\section{М.Д. Маргариту, Е. Цанатос}

Континуирани притисак за смањење трошкова енергије, као и већа потреба за контролу климатских промена и деградације квалитета ваздуха довела је до значајног помака у еколошкој свести кроз примену строжије политике и законодавства. Напори за уштеду енергије морају бити присутни у свим енергетски интензивним секторима, као што су индустрија и транспорт (на копну, мору или у ваздуху). Прихваћена је чињеница да је поморски транспорт главни извор емисије издувних гасова. Зато су научна истраживања усмерена на развијање и примену различитих техничких и оперативних решења за смањење издувних гасова са бродова чији мотори користе лаку и тешку нафту као гориво. Примена технологија обновљиве енергије на броду можда представља изводљиву опцију у односу на различите техничке и оперативне критеријуме везане за бродове. Рад приказује законски оквир који упућује на потребу да се следи истраживачки изазов, истиче расположиве опције које се уклапају у овај оквир и истражује могућност увођења обновљивог хибридног енергетског система, при чему је проучено једно одређено пловило. 